\title{
Az egészségügyi szakdolgozókat ért agresszív cselekmények kapcsolata szociodemográfiai és munkahelyi tényezőkkel
}

\author{
Irinyi Tamás ${ }^{1}$ - Németh Anikó dr. ${ }^{2}$ - Lampek Kinga dr. ${ }^{3}$ \\ 'Szegedi Tudományegyetem, Általános Orvostudományi Kar, Szent-Györgyi Albert Klinikai Központ, \\ Pszichiátriai Klinika, Szeged \\ ${ }^{2}$ Szegedi Tudományegyetem, Egészségtudományi és Szociális Képzési Kar, \\ Egészségmagatartás és -fejlesztés Szakcsoport, Szeged \\ ${ }^{3}$ Pécsi Tudományegyetem, Egészségtudományi Kar, Egészségbiztosítási Intézet, \\ Egészségfejlesztési és Népegészségtani Tanszék, Pécs
}

\begin{abstract}
Bevezetés: Manapság egyre többet lehet hallani az egészségügyi dolgozók ellen elkövetett agresszív cselekményekről. Ez a terület külföldön már évek óta a figyelem középpontjában van, és számtalan ezzel kapcsolatos kutatás született, de hazai viszonylatban ezen a téren nagy hiányosságok mutatkoznak. Célkitüzés: Feltárni az egészségügyi szakdolgozókat ért agresszív cselekmények és azok hatásának összefüggéseit különböző szociodemográfiai és munkahelyi tényezőkkel. Módszer: Kvantitatív keresztmetszeti vizsgálat online kérdőívvel 1201 egészségügyi szakdolgozó részvételével. Az adatelemzés $\chi^{2}$-, Kolmogorov-Szmirnov-, Mann-Whitney- és Kruskal-Wallis-próbával történt. Eredmények: A férfiak, az 50 évesnél fiatalabb munkavállalók, a fekvőbeteg-ellátásban, a 12 órás folyamatos munkarendben és az állandóan éjszaka dolgozók, a havonta valamennyi túlórát végzők élnek át jelentôsen gyakrabban verbális és fizikális agressziót, és az agresszív incidens következtében kialakult negatív emocionális hatás is ezen csoportoknál jelentkezik inkább. Következtetések: Az agresszió a hazai egészségügyben egy jelen lévő és súlyos probléma, amely megköveteli a dolgozók megfelelő felkészítését az ilyen esetekre. Orv. Hetil., 2017, 158(6), 229-237.
\end{abstract}

Kulcsszavak: egészségügyi dolgozók, munkahelyi agresszió, agresszió hatása

\section{Violence against health care providers and its correlations with sociodemographic and workplace-related factors}

Introduction: Violence against health care providers is getting more awareness nowadays. This topic is in the focus of international scientific attention also, although in Hungary exact data is lacking. Aim: The present study aimed to assess the correlations between violent acts against health care workers and their effects with different sociodemographic and workplace-related factors. Method: A quantitative cross-sectional online survey was conducted enrolling 1201 health care providers. Data were analysed trough chi-square, Kolmogorov-Smirnov, Mann-Whitney and Kruskal-Wallis tests, where appropriate. Results: Verbal and physical aggression was experienced more frequently by nurses who were males, above the age of fifty, working in in-patient care or in 12 hours shifts or constant night shifts. The same groups of health care providers suffered more from the negative emotional consequences of violent acts. Conclusions: Aggression is a serious problem in the Hungarian health care system, therefore employees have to be prepared for these acts.

Keywords: healthcare workers, workplace aggression, effect of aggression

Irinyi, T., Németh, A., Lampek, $K$. [Violence against health care providers and its correlations with sociodemographic and workplace-related factors]. Orv. Hetil., 2017, 158(6), 229-237.

(Beérkezett: 2016. november 3.; elfogadva: 2016. december 12.) 


\section{Rövidítések}

IMPACS = Impact of Patient Aggression on Carers Scale; NEFMI $=$ Nemzeti Erőforrás Minisztérium

Az agresszió olyan szándékos viselkedés, amely fizikailag vagy verbálisan sérülést okoz más embernek, de irányulhat tárgy ellen is. Általában haragra adott válaszreakció, amit drive-ként tanult válaszként emlegetnek a pszichológiában. „Agressziónak nevezünk minden olyan szándékos cselekvést, amelynek inditéka, hogy - nyilt vagy szimbolikus formában - valakinek vagy valaminek kárt, sérelmet vagy fájdalmat okozzon" [1]. Magnativa és Heponiemi a munkahelyi erőszakot egy „eröszakos cselekménynek definiálja, amely közvetlenül a dolgozóra irányul, magába foglalja a fizikai támadást, a támadással való fenyegetést, a szóbeli bántalmazást, és hosszú távú következménye van a dolgozó egészségére és biztonságára nézve” [2]. Az egészségügyben számos ok lehet a beteg és a hozzátartozó részéről, amely agresszív cselekményt indukálhat. Ezek között szerepel többek között az alkohol vagy kábítószer okozta befolyásoltság [3], szkizofrénia, major depreszszió, bipoláris személyiségzavar [4], hosszú várakozási idő [5], szûk hely, túlzsúfoltság [6], az egészségügyi ellátással való elégedetlenség, rossz hír közlése, késedelmes ellátás [7]. Következményesen kialakulhat fájdalom, szükség lehet orvosi kezelésre is [8], de a fizikai sérülésen kívül talán súlyosabbak a lelki kihatások: stressz, félelem, fóbiák, alvászavar, csökkent önbecsülés [9], harag, csalódottság, kétségbeesés, tehetetlenség és reménytelenség, közöny, neheztelés, illetve olyan megküzdési mechanizmusok alakulnak ki, mint a szerhasználat (alkohol, kábítószer) és a „nem tudok ápolni” attitűd [10]. Olyan hosszú távú pszichés következményei is lehetnek, mint a poszttraumás stressz és a kiégés [11]. Egy hazai kutatás szerint a fiatalabb dolgozók kevésbé tudják kezelni az agresszív betegeket, az incidens után gyakran zavart ápoló-beteg kapcsolatról számolnak be, kevésbé érzik magukat biztonságban munka közben, kerülik a kapcsolatot a bántalmazó beteggel, és ritkábban éreznek sajnálatot, mint idősebb kollégáik. Jellemző továbbá, hogy az incidens után a munkáltatójuktól kevés segítséget kapnak, inkább munkatársaikra számíthatnak ezen a téren [12].

Az 1997. évi CLIV. törvény 139. \$ alapján „Az egészségügyi dolgozó [...] a betegellátással és a betegirányitással közvetlenül összefüggö feladatai tekintetében közfeladatot ellátó személynek minösül”[13]. A 2012. évi C. törvény a Büntető Törvénykönyv 310. $\$$ (1) kimondja, hogy „Aki hivatalos vagy külföldi hivatalos személyt [...] c) eljárása alatt, illetve emiatt bántalmaz, büntett miatt egy évtôl öt évig terjedó szabadságvesztéssel büntetend"o”. A 311. \$ leírja, hogy „A 310. \$ szerint büntetendo", aki az ott meghatározott büncselekményt közfeladatot ellátó személy ellen követi el”[14]. Ezekből az idézett törvényekből megállapítható, hogy Magyarországon zéró tolerancia van érvényben az egészségügyi dolgozókkal szemben elköve- tett erőszakkal kapcsolatban, tehát ha egy beteg vagy hozzátartozója egészségügyi dolgozót bántalmaz, annak büntetőjogi következményei lesznek. Kevés hazai adat van arról, hogy a magyar egészségügyben évente mennyi erőszakos cselekményt élnek át a dolgozók. Az esetek egy részét nem jelentik sem feletteseiknek, sem a hatóságoknak. A rendőrség bünügyi statisztikai rendszere szerint 2015-ben 139 esetben volt a sértett felsőfokú képesítéssel rendelkező ápoló, 639 esetben szakápoló, 180 esetben orvos, 117 esetben általános egészségügyi aszszisztens [15]. Eddig egyetlen felmérés készült hazánkban egészségügyi szakdolgozók körében, amely az agresszió előfordulását kutatta. A 453 egészségügyi dolgozó közül 81,6\% jelezte, hogy a beteg emelkedett hangon beszélt vele, fizikai bántalmazást (ruha megragadása, rángatás) 19,9\% szenvedett el, fizikai sérülést (enyhe sérülés, funkcionális károsodás, de egészségügyi ellátásra nem volt szükség) pedig 21\%. Az 50 év feletti válaszadók körében a fizikai és a verbális agresszió is jelentősen kevesebbszer fordul elő, mint fiatalabb kollégáik esetében [12].

Az áttekintett hazai szakirodalom hiányosságot mutat az egészségügyi szakdolgozók által elszenvedett agreszszió és annak következményeit kutató tanulmányok terén, ezért vizsgálatunk célja az volt, hogy egy országos felmérés keretein belül megvizsgáljuk a dolgozókat ért agresszív cselekmények fajtáit, gyakoriságát, valamint azt, hogy milyen következményei lesznek az átélt agreszszív incidensnek, illetve kiktől kapnak segítséget a bántalmazás után a válaszadók. Mindezeket összefüggésben kívántuk vizsgálni különböző szociodemográfiai és munkahelyi tényezőkkel.

\section{Módszer}

A kvantitatív keresztmetszeti vizsgálat 2016. június 29től augusztus 31-ig történt egy saját szerkesztésű online kérdőívvel, amely a szociodemográfiai és saját készítésú kérdéseken túl tartalmazta többek között az Overt agresszióskálát [16] és az agresszív incidens következtében kialakult negatív emocionális hatások felmérésére szolgáló skálát [17]. A felmérést a Magyar Egészségügyi Szakdolgozói Kamara Országos és Területi Szervezeteinek segítségével végeztük, a tagokat e-mail útján és a szervezet közösségi oldalain keresztül értük el, kényelmi mintavételt alkalmaztunk, az egyszerúen elérhető alanyokra támaszkodtunk. A beválasztási kritériumok a következők voltak: legalább egyéves munkaviszony az egészségügyben, teljes állásban, magyarországi munkavégzés, illetve a 63/2011-es NEFMI rendeletben meghatározott egészségügyi szakdolgozói képesítés [18]. Összesen 1341 kitöltés érkezett, ebből törlésre kerültek azok, akik nem feleltek meg a beválasztási kritériumoknak: a külföldön dolgozók, a nyugdíjasok, nem egészségügyi szakdolgozók, illetve azok, akik duplán töltötték ki a kérdőívet. Így az adatelemzés során 1201 válaszadó válaszait elemeztük IBM SPSS 23.0 for Windows statisztikai programmal, $\chi^{2}$ - 


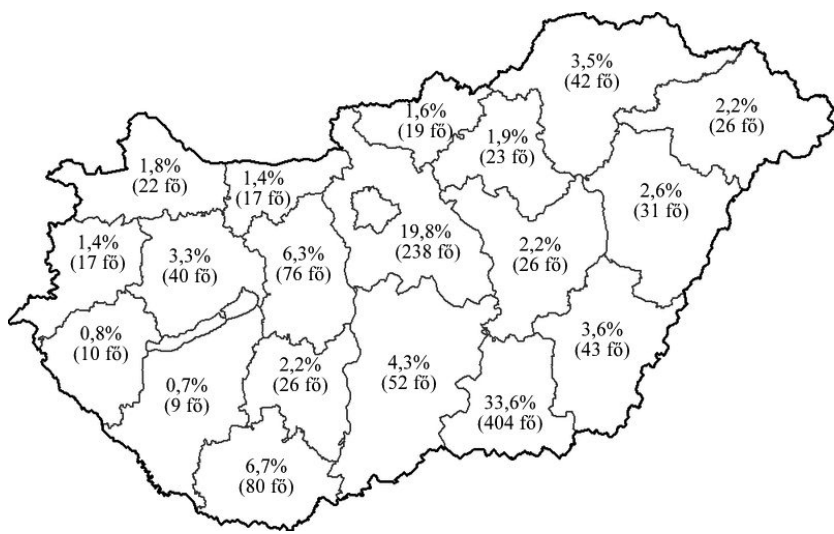

1. ábra

| A válaszadók megyék szerinti megoszlása $(\mathrm{N}=1201)$

próbával (nominális adatoknál), Kolmogorov-Szmirnov-, Mann-Whitney- és Kruskal-Wallis-próbával. A szignifikancia kritériumhatára $\mathrm{p}<0,05$. Az agresszió és annak hatásának vizsgálatánál független változóként a nemet, az életkort (tízéves bontásban), a végzettséget és az egészségügyi ellátás szintjét, a havi túlóra meglétét és a munkarendet (múszakbeosztás) szerepeltettük.

\section{Eredmények}

Az 1201 válaszadó 92,5\%-a (1111 fö) nő, 7,5\%-a (90 fó) pedig férfi. Átlagéletkoruk 43,16 év (medián: 44 év; SD:
9,283; minimum: 19; maximum: 65). 10,3\% tartozik a 19-29 éves, 20,6\% a 30-39 éves, 41,2\% a 40-49 éves, $27,8 \%$ az 50 év feletti korosztályba. Az iskolai végzettséget tekintve $75,2 \%$ ápoló, $13,2 \%$ asszisztens, $3,2 \%$ védőnő, 1,5\% gyógytornász, 1,3\% szülésznő, 1,1\% mentőtiszt, $0,9 \%$ dietetikus, és $3,7 \%$ rendelkezik egyéb egészségügyi képesítéssel, például gyógyászati segédeszközt forgalmazó, műtőssegéd, népegészségügyi ellenőr, egészségügyi menedzser, szakoktató, szaktanár, gyógymasszőr. A diplomások a minta 34,9\%-át teszik ki. A válaszadók megyék szerinti megoszlását az 1 . ábra szemlélteti. Jelentős többség $(33,6 \%)$ Csongrád megyei, illetve 19,8\% Pest megyei, a többi megyéből ennél lényegesen kevesebb válasz érkezett.

A munkahelyi jellemzőket elemezve megállapítható, hogy a felmérésben részt vevők átlag 22,09 éve dolgoznak az egészségügyben (medián: 24 év; SD: 10,92; minimum: 1; maximum: 46). Az egészségügyi ellátás szintjét vizsgálva pedig elmondható, hogy $15,7 \%$ dolgozik az alapellátásban, 20,7\% a járóbeteg-ellátásban, 62,4\% a fekvőbeteg-ellátásban és 1,2\% gyógyszertárban, akik egyik ellátási típusba sem sorolhatók be. $26,4 \%$ egyáltalán nem végez havonta túlórát, a többi válaszadó átlag 25,9 órát túlórázik egy hónapban (medián: 140,5; SD: 28,85; minimum: 1; maximum: 280). A múszakbeosztás elemzése során megállapítható, hogy $38,2 \%$ dolgozik folyamatos múszakbeosztásban, 12 órás munkarendben, és majdnem ugyanennyien dolgoznak állandó délelőtti mú-

1. táblázat |Az átélt agresszív cselekmények gyakorisága a nemek függvényében

\begin{tabular}{|c|c|c|c|c|c|}
\hline & \multicolumn{4}{|c|}{ Agresszió átélésének gyakorisága (\%) } & \multirow[t]{3}{*}{$\mathrm{p}$} \\
\hline & Soha & $\begin{array}{l}\text { Kevesebb mint } \\
10 \text { alkalommal }\end{array}$ & $\begin{array}{l}10-20 \\
\text { alkalommal }\end{array}$ & $\begin{array}{l}20 \text { alkalomnál } \\
\text { többször }\end{array}$ & \\
\hline Nem: & $\mathrm{F} / \mathrm{N}$ & $\mathrm{F} / \mathrm{N}$ & $\mathrm{F} / \mathrm{N}$ & $\mathrm{F} / \mathrm{N}$ & \\
\hline Verbális agresszió & & & & & \\
\hline A beteg emelkedett hangon beszélt velem. & $6,7 / 6$ & $16,7 / 38,2$ & $24,4 / 19,3$ & $52,2 / 36,5$ & $=0,001$ \\
\hline A beteg csúnya szavakkal illetett vagy átkokat szórt rám. & $15,6 / 24,3$ & $23,3 / 39,3$ & $14,4 / 13,3$ & $46,7 / 23$ & $<0,001$ \\
\hline A beteg megfenyegetett. & $27,8 / 38,3$ & $22,2 / 37,8$ & $14,4 / 11,5$ & $35,6 / 12,4$ & $<0,001$ \\
\hline $\begin{array}{l}\text { A beteg hangosan kiabált velem és egyértelmúvé tette, ha nem } \\
\text { teszem, amit mond, fizikailag bántalmazni fog. }\end{array}$ & $38,9 / 55,6$ & $24,4 / 28$ & $10 / 8$ & $26,7 / 8,4$ & $<0,001$ \\
\hline Fizikális agresszió & & & & & \\
\hline A beteg agressziója tárgyra irányult. & $28,9 / 45,9$ & $35,6 / 35,3$ & $14,4 / 9,6$ & $21,1 / 9,2$ & $<0,001$ \\
\hline A beteg megragadta a ruhámat vagy megrángatott. & $37,8 / 65,6$ & $43,3 / 25,6$ & $7,8 / 5$ & $11,1 / 3,8$ & $<0,001$ \\
\hline $\begin{array}{l}\text { A beteg enyhe sérülést vagy funkcionális károsodást okozott } \\
\text { nekem, de nem volt szükség egészségügyi ellátásra. }\end{array}$ & $56,7 / 74$ & $34,4 / 22,2$ & $4,4 / 2,5$ & $4,4 / 1,3$ & $=0,001$ \\
\hline $\begin{array}{l}\text { A beteg közepes sérülést vagy funkcionális károsodást okozott } \\
\text { nekem, szükség volt egészségügyi ellátásra, de nem volt } \\
\text { szükség kórházi befekvésre. }\end{array}$ & $88,9 / 93,6$ & $7,8 / 5,7$ & $1,1 / 0,3$ & $2,2 / 0,5$ & 0,069 \\
\hline $\begin{array}{l}\text { A beteg súlyos sérülést vagy funkcionális károsodást okozott } \\
\text { nekem, szükség volt egészségügyi ellátásra, de nem volt } \\
\text { szükség kórházi befekvésre. }\end{array}$ & $95,6 / 97,5$ & $2,2 / 2$ & $1,1 / 0,2$ & $1,1 / 0,4$ & 0,254 \\
\hline $\begin{array}{l}\text { A beteg súlyos sérülést vagy funkcionális károsodást okozott } \\
\text { nekem, szükség volt kórbázi befekvésre. }\end{array}$ & $98,9 / 98,7$ & $1,1 / 1,1$ & - & $0 / 0,2$ & 0,922 \\
\hline
\end{tabular}

$\mathrm{F}=$ férfi; $\mathrm{N}=$ nő $(\mathrm{N}=1201)$. 
szakban $(34,9 \%)$. Az állandó nappalos $(5,1 \%)$, a nyolcórás folyamatos munkarendet $(9,2 \%)$ és a délelőttös és délutános múszak váltakozását $(9,6 \%)$ lényegesen kevesebben jelölték meg, állandó éjszakás $1 \%$. Az egyéb válaszlehetőséget is megjelölte 2\%. Közülük 5-5 fö jelezte a 8 és 12 órás múszakok váltakozását és az ügyeleti munkarendet, 6 fó a kötetlen munkaidőt. Három fó változó munkaidőt jelölt meg, és további egy-egy válasz érkezett az alábbiakból: 10 és 12 órás múszak váltakozik, 11 és 12 órás mûszak váltakozik, 9 és 12 órás müszak váltakozik, állandó délután, szombaton és délután behívás alapján.

A munka során elszenvedett agresszív cselekmények vizsgálata az Overt agresszióskála segítségével történt, amely egy 10 kérdésből álló mérőeszköz. A kérdések két csoportba oszthatók, az agresszív cselekmények verbális és fizikális mintázataiba [16]. Felmérésünkben nem vizsgáltuk, hogy az agresszív cselekményt a beteg vagy a hozzátartozó követte el. Az egyes agressziótípusok nemenkénti megoszlását vizsgálva megállapítható, hogy a verbális agresszió minden típusát egyértelmúen a férfiak élik át szignifikánsan gyakrabban, és ugyanez igaz a fizikális agresszió közül a tárgyra irányuló agresszióra, a ruha megragadására és az enyhe sérülés elszenvedésére (1. táblázat).

Az egyes életkori csoportokat elemezve megállapítottuk, hogy egészségügyi pályafutása során a 30 év alattiak 38,7\%-át, a 30-39 évesek 42,7\%-át, a 40-49 évesek 39,6\%-át, az 50 év felettiek 32,7\%-át illette a beteg vagy hozzátartozója legalább 10 alkalommal csúnya szavakkal, a különbség a csoportok között jelentős $(p=0,013)$. Fenyegetésben legalább 10 alkalommal a 30 év alattiak 25,8\%-a, a 30-39 évesek 29,4\%-a, a 40-49 évesek 28,5\%-a, az 50 év felettiek 19,5\%-a részesült pályája során, a különbség gyengén ugyan, de itt is szignifikáns $(\mathrm{p}=0,049)$. A beteg vagy hozzátartozója legalább 10 alkalommal kiabált a 30 év alattiak 19,4\%-ával, a 30-39 évesek 23\%-ával, a 40-49 évesek 17,6\%-ával, az 50 év felettiek 14,4\%-ával, a különbség a csoportok között jelentős $(\mathrm{p}=0,020)$. Enyhe sérülést a 30 év alattiak 4,8\%-a, a 30-39 évesek 6\%-a, a 40-49 évesek 3,4\%-a, az 50 év felettiek 3,6\%-a szenvedett el munkája során legalább 10 alkalommal $(\mathrm{p}=0,008)$. A többi agressziótípusban nem mutatkozott szignifikáns különbség az egyes életkori csoportok között.

A diploma megléte egyik agressziótípus esetében sem mutatott összefüggést annak átélési gyakoriságával.

Az egészségügyben, különösen a fekvőbeteg-ellátásban dolgozók veszélyeztetettek az agresszióra. Egészségügyi munkájuk során legalább 10 alkalommal a verbális agresszió összes típusát, illetve a tárgyra irányuló agressziót, a ruha megragadását és az enyhe sérülést is ezen a területen dolgozók élték át leginkább (2. táblázat).

Szinte minden munkaterületről érkeztek válaszok, így kiválasztottuk azt az öt területet, ahonnan a legtöbb kitöltés érkezett. A sürgősségi betegellátást és a mentés-
2. táblázat $\mid$ Az egészségügyi ellátás szintjének összefüggése az átélt agreszszió típusával $(\mathrm{N}=1201)$

\begin{tabular}{|c|c|c|c|c|c|}
\hline \multirow[b]{2}{*}{ Egészségügyi ellátás szintje: } & \multicolumn{4}{|c|}{$\begin{array}{l}\text { Agresszió átélésének } \\
\text { gyakorisága (\%) }\end{array}$} & \multirow[t]{2}{*}{$\mathrm{p}$} \\
\hline & Alap & Járó & Fekvő & $\begin{array}{l}\text { Gyógy- } \\
\text { szertár }\end{array}$ & \\
\hline \multicolumn{6}{|c|}{ Verbális agresszió - legalább 10 alkalommal } \\
\hline Emelkedett hangnem & 48,4 & 56,6 & 60,5 & 26,7 & $=0,012$ \\
\hline Csúnya szavak & 25,5 & 32,2 & 43,8 & 20 & $<0,001$ \\
\hline Fenyegetés & 16,5 & 19,6 & 30,9 & 0 & $<0,001$ \\
\hline Kiabálás & 9,6 & 8,4 & 23,5 & 0 & $<0,001$ \\
\hline \multicolumn{6}{|c|}{ Fizikális agresszió - legalább 10 alkalommal } \\
\hline Tárgyra irányuló agresszió & 11,2 & 8 & 26,6 & 6,7 & $<0,001$ \\
\hline Ruha megragadása & 2,6 & 3,2 & 13,6 & 0 & $<0,001$ \\
\hline Enyhe sérülés & 0 & 1,2 & 6,2 & 0 & $<0,001$ \\
\hline Közepes sérülés & 0,5 & 0,4 & 1,2 & 0 & 0,089 \\
\hline Súlyos sérülés & 0,5 & 0 & 0,9 & 0 & 0,705 \\
\hline Kórházi befekvés & 0 & 0 & 0,3 & 0 & 0,820 \\
\hline
\end{tabular}

ügyet összevontuk, mivel külön-külön kevés válasz érkezett, ami nagymértékben torzította volna a statisztikai próba eredményét. A 3. táblázatból egyértelmúen megállapítható, hogy a pszichiátrián dolgozó ápolók jelentősen gyakrabban élnek át agresszív cselekményt, mint a más területen dolgozók. Az összes, általunk feltüntetett agressziótípus esetében igaz ez $(\mathrm{p}<0,001)$. Az emelkedett hangnem $(63,9 \%)$, a csúnya szavakkal történő illetés $(55,4 \%)$, a fenyegetés $(37,3 \%)$, a ruha megragadása $(15,7 \%)$ és az enyhe sérülés $(4,8 \%)$ megtapasztalása az ezen az osztályon dolgozó ápolókat érinti leginkább. Ezeket az incidenseket egészségügyi munkájuk során ők tapasztalták meg 20 alkalomnál is többször. Az SBO-n és mentésügyben dolgozó kollégák közül igen magas az emelkedett hangnem, a csúnya szavak és a fenyegetés megtapasztalása (3. táblázat).

Szignifikáns összefüggést tudtunk kimutatni az elszenvedett agresszió gyakorisága és a túlórázás ténye között. A verbális agresszió minden formáját jelentősen gyakrabban élik át azok a válaszadók, akik havonta végeznek valamennyi túlórát. A fizikális agresszió átélésének gyakoriságában a súlyos sérülés és a kórházi befekvést igénylő súlyos sérülés kivételével szintén jelentős különbség mutatkozott a túlórázók és a nem túlórázók között (4. táblázat).

A munkarend szintén majdnem mindegyik agressziótípussal szignifikáns összefüggést mutat. Az 5. táblázatban látható, hogy az emelkedett hangnemet a 12 órás folyamatos munkarendben és az állandó éjszaka dolgozók élték át jelentösen gyakrabban $(\mathrm{p}=0,001)$, a csúnya szavakkal való illetést, a fenyegetést, a kiabálást, a tárgyra irányuló agressziót, a ruha megragadását és az enyhe sérülést szintén az állandó éjszakások élték át szignifikánsan gyakrabban $(\mathrm{p}<0,001)$. Közepes sérülést az állandó nappalosok és a 12 órás müszakbeosztásban dolgozók 
3. táblázat $\mid$ Az átélt agresszív cselekmények gyakorisága a munkaterület függvényében $(\mathrm{N}=1201)$

\begin{tabular}{|c|c|c|c|c|c|}
\hline \multirow{2}{*}{$\begin{array}{l}\text { Munka- } \\
\text { terület }\end{array}$} & \multirow{2}{*}{$\begin{array}{l}\text { Agresszió } \\
\text { típusa }\end{array}$} & \multicolumn{4}{|c|}{ Agresszió átélésének gyakorisága (\%) } \\
\hline & & Soha & $\begin{array}{l}\text { Keve- } \\
\text { sebb } \\
\text { mint } 10 \\
\text { alka- } \\
\text { lommal }\end{array}$ & $\begin{array}{l}10-20 \\
\text { alkalom- } \\
\text { mal }\end{array}$ & $\begin{array}{l}20 \\
\text { alkalom- } \\
\text { nál } \\
\text { többször }\end{array}$ \\
\hline \multirow[t]{5}{*}{$\begin{array}{l}\mathrm{SBO}+ \\
\text { mentésügy }\end{array}$} & $\begin{array}{l}\text { Emelkedett } \\
\text { hang }\end{array}$ & 3,3 & 11 & 23,1 & 62,6 \\
\hline & Csúnya szavak & 5,5 & 23,1 & 14,3 & 57,1 \\
\hline & Fenyegetés & 11 & 28,6 & 23,1 & 37,4 \\
\hline & $\begin{array}{l}\text { Ruha } \\
\text { megragadása }\end{array}$ & 45,1 & 42,9 & 6,6 & 5,5 \\
\hline & Enyhe sérülés & 52,7 & 38,5 & 6,6 & 2,2 \\
\hline \multirow[t]{5}{*}{ Pszichiátria } & $\begin{array}{l}\text { Emelkedett } \\
\text { hang }\end{array}$ & 1,2 & 19,3 & 15,7 & 63,9 \\
\hline & Csúnya szavak & 7,2 & 22,9 & 14,5 & 55,4 \\
\hline & Fenyegetés & 14,5 & 32,5 & 15,7 & 37,3 \\
\hline & $\begin{array}{l}\text { Ruha } \\
\text { megragadása }\end{array}$ & 33,7 & 39,8 & 10,8 & 15,7 \\
\hline & Enyhe sérülés & 38,6 & 49,4 & 7,2 & 4,8 \\
\hline \multirow[t]{5}{*}{ Sebészet } & $\begin{array}{l}\text { Emelkedett } \\
\text { hang }\end{array}$ & 6,1 & 42,1 & 14 & 37,7 \\
\hline & Csúnya szavak & 23,7 & 42,1 & 8,8 & 25,4 \\
\hline & Fenyegetés & 45,6 & 30,7 & 12,3 & 11,4 \\
\hline & $\begin{array}{l}\text { Ruha } \\
\text { megragadása }\end{array}$ & 57 & 28,1 & 13,2 & 1,8 \\
\hline & Enyhe sérülés & 69,3 & 25,4 & 3,5 & 1,8 \\
\hline \multirow[t]{5}{*}{$\begin{array}{l}\text { Bel- } \\
\text { gyógyászat }\end{array}$} & $\begin{array}{l}\text { Emelkedett } \\
\text { hang }\end{array}$ & 4,7 & 37,2 & 14,7 & 43,4 \\
\hline & Csúnya szavak & 17,8 & 40,3 & 12,4 & 29,5 \\
\hline & Fenyegetés & 29,5 & 42,6 & 10,9 & 17,1 \\
\hline & $\begin{array}{l}\text { Ruha } \\
\text { megragadása }\end{array}$ & 56,6 & 28,7 & 7,8 & 7 \\
\hline & Enyhe sérülés & 65,9 & 26,4 & 6,2 & 1,6 \\
\hline \multirow[t]{5}{*}{$\begin{array}{l}\text { Gyermek- } \\
\text { gyógyászat }\end{array}$} & $\begin{array}{l}\text { Emelkedett } \\
\text { hang }\end{array}$ & 5,5 & 56 & 12,1 & 26,4 \\
\hline & Csúnya szavak & 38,5 & 35,2 & 12,1 & 14,3 \\
\hline & Fenyegetés & 52,7 & 30,8 & 7,7 & 8,8 \\
\hline & $\begin{array}{l}\text { Ruha } \\
\text { megragadása }\end{array}$ & 82,4 & 17,6 & 0 & 0 \\
\hline & Enyhe sérülés & 90,1 & 9,9 & 0 & 0 \\
\hline
\end{tabular}

1,6-1,6\%-a élte át munkája során legalább tíz alkalommal, ami jelentősen több, mint a többi munkarendtípusban dolgozók esetében $(\mathrm{p}=0,023)$ (5. táblázat).

A felmérésben részt vevőknek csupán 4,4\%-a jelezte, hogy amióta az egészségügyben dolgozik, még soha nem élt át agresszív eseményt munkája során.

Az agresszív incidens következtében kialakult negatív hatásokat méró (Impact of Patient Aggression on Carers Scale - IMPACS) tíz, Likert-típusú kérdést tartalmazó
4. táblázat $\mid$ Az átélt agresszív cselekmények gyakorisága a túlórázás függvényében

\begin{tabular}{|c|c|c|c|c|c|}
\hline & \multicolumn{4}{|c|}{ Agresszió átélésének gyakorisága (\%) } & \multirow[t]{2}{*}{$\mathrm{p}$} \\
\hline & Soha & $\begin{array}{l}\text { Kevesebb } \\
\text { mint } 10 \\
\text { alkalommal }\end{array}$ & $\begin{array}{l}10-20 \\
\text { alkalommal }\end{array}$ & $\begin{array}{l}20 \\
\text { alkalomnál } \\
\text { többször }\end{array}$ & \\
\hline $\begin{array}{l}\text { Túlórá- } \\
\text { zik-e? }\end{array}$ & $\mathrm{N} / \mathrm{I}$ & $\mathrm{N} / \mathrm{I}$ & $\mathrm{N} / \mathrm{I}$ & $\mathrm{N} / \mathrm{I}$ & \\
\hline \multicolumn{6}{|c|}{ Verbális agresszió } \\
\hline $\begin{array}{l}\text { Emel- } \\
\text { kedett } \\
\text { hangnem }\end{array}$ & $8,2 / 5$ & $43,5 / 34,2$ & $16,4 / 20,8$ & $31,9 / 40$ & $=0,001$ \\
\hline $\begin{array}{l}\text { Csúnya } \\
\text { szavak }\end{array}$ & $30,9 / 20,8$ & $40,7 / 37,4$ & $14,2 / 13,1$ & $14,2 / 28,7$ & $<0,001$ \\
\hline $\begin{array}{l}\text { Fenye- } \\
\text { getés }\end{array}$ & $47,9 / 33,7$ & $35,6 / 36,9$ & $9,8 / 12,6$ & $6,6 / 16,8$ & $<0,001$ \\
\hline Kiabálás & $69,7 / 48,8$ & $21,8 / 29,8$ & $5 / 9,4$ & $3,5 / 12$ & $<0,001$ \\
\hline \multicolumn{6}{|c|}{ Fizikális agresszió } \\
\hline $\begin{array}{l}\text { Tárgyra } \\
\text { irányuló } \\
\text { agresszió }\end{array}$ & $58,4 / 39,5$ & $30,9 / 37,1$ & $5,7 / 11,4$ & $5 / 11,9$ & $<0,001$ \\
\hline $\begin{array}{l}\text { Ruha } \\
\text { meg- } \\
\text { ragadása }\end{array}$ & $78,2 / 58,1$ & $18 / 30,4$ & $1,9 / 6,5$ & $1,9 / 5$ & $<0,001$ \\
\hline $\begin{array}{l}\text { Enyhe } \\
\text { sérülés }\end{array}$ & $84,5 / 68,6$ & $14,2 / 26,3$ & $0,9 / 3,3$ & $0,3 / 1,8$ & $<0,001$ \\
\hline $\begin{array}{l}\text { Közepes } \\
\text { sérülés }\end{array}$ & $97,2 / 92,1$ & $2,5 / 6,9$ & $0 / 0,5$ & $0,3 / 0,6$ & 0,018 \\
\hline $\begin{array}{l}\text { Súlyos } \\
\text { sérülés }\end{array}$ & $99,1 / 96,8$ & $0,9 / 2,4$ & $0 / 0,3$ & $0 / 0,5$ & 0,165 \\
\hline $\begin{array}{l}\text { Kórházi } \\
\text { befekvés }\end{array}$ & $99,7 / 98,4$ & $0,3 / 1,4$ & - & $0 / 0,2$ & 0,208 \\
\hline
\end{tabular}

$\mathrm{N}=$ nem; $\mathrm{I}=\operatorname{igen}(\mathrm{N}=1201)$.

mérôeszköz egyes kérdéseit $1-5$-ig lehet pontozni $(1=$ soha; $2=$ ritkán; $3=$ néha; $4=$ gyakran; $5=$ majdnem mindig). Magasabb pontszám súlyosabb negatív emocionális hatást jelöl [17]. A tíz kérdés három alskálára bontható: kapcsolatromlás a beteg és az ellátó között (négy kérdés; Cronbach-alfa: 0,78), súlyos negatív emocionális hatás az ellátóra (négy kérdés; Cronbach-alfa: 0,68 ), ellenséges érzelmek a külvilággal szemben (két kérdés; Cronbach-alfa: 0,60). A három alskála egyike sem normális eloszlású, mivel az elvégzett KolmogorovSzmirnov-teszt mindhárom esetben szignifikanciát mutatott $(p<0,001)$. Ezen ok miatt nemparaméteres statisztikai próbákkal végeztük az adatelemzést. A válaszadók közül 53 fó jelezte, hogy amióta az egészségügyben dolgozik, semmiféle agresszió nem érte, így ők az IMPACS skálát sem töltötték ki. A három leggyakoribb hatás, amely az agresszív cselekmény után bekövetkezett: az agresszív beteggel való kapcsolat kerülése, sajnálat az agresszív beteg iránt, „úgy érzem, társadalmi problémákkal kell foglalkoznom". Ezen három válasznál a kitöltók több mint $20 \%$-a jelölte be a gyakran és a majdnem mindig válaszlehetőséget (6. táblázat). Az első alskálán átlag 
5. táblázat $\mid A z$ átélt agresszív cselekmények gyakorisága a munkarend függvényében $(\mathrm{N}=1201)$

\begin{tabular}{|c|c|c|c|c|c|c|c|c|}
\hline \multirow[b]{2}{*}{ Munkarend: } & \multicolumn{7}{|c|}{ Agresszió átélésének gyakorisága (\%) } & \multirow[t]{2}{*}{$\mathrm{p}$} \\
\hline & $\begin{array}{l}\text { Állandó } \\
\text { délelőtt }\end{array}$ & $\begin{array}{l}\text { Állandó } \\
\text { nappal }\end{array}$ & $\begin{array}{l}\text { Délelőttös } \\
\text { és délutános } \\
\text { múszak } \\
\text { váltakozik }\end{array}$ & $\begin{array}{l}\text { Folyamatos } \\
\text { ( } 8 \text { órás) }\end{array}$ & $\begin{array}{l}\text { Folyamatos } \\
\text { (12 órás) }\end{array}$ & $\begin{array}{l}\text { Állandó } \\
\text { éjszaka }\end{array}$ & Egyéb & \\
\hline \multicolumn{9}{|c|}{ Verbális agresszió - legalább 10 alkalommal } \\
\hline Emelkedett hangnem & 50,6 & 50,9 & 57,4 & 50 & 66,5 & 61,5 & 50,1 & $=0,001$ \\
\hline Csúnya szavak & 29,6 & 39,3 & 24,4 & 29,1 & 50,5 & 61,5 & 29,2 & $<0,001$ \\
\hline Fenyegetés & 15,9 & 32,8 & 10,4 & 18,2 & 39,4 & 46,2 & 20,8 & $<0,001$ \\
\hline Kiabálás & 10 & 21,3 & 3,4 & 13,7 & 28,8 & 46,2 & 12,5 & $<0,001$ \\
\hline \multicolumn{9}{|c|}{ Fizikális agresszió - legalább 10 alkalommal } \\
\hline $\begin{array}{l}\text { Tárgyra irányuló } \\
\text { agresszió }\end{array}$ & 14,4 & 13,2 & 6 & 12,8 & 30,5 & 53,9 & 20,8 & $<0,001$ \\
\hline Ruha megragadása & 3,1 & 9,9 & 0,9 & 8,2 & 17,7 & 38,5 & 0 & $<0,001$ \\
\hline Enyhe sérülés & 1 & 3,2 & 0,9 & 3,6 & 8,1 & 15,4 & 0 & $<0,001$ \\
\hline Közepes sérülés & 0,4 & 1,6 & 0 & 0,9 & 1,6 & 0 & 0 & 0,023 \\
\hline Súlyos sérülés & 0,5 & 0 & 0 & 0,9 & 1,1 & 0 & 0 & 0,723 \\
\hline Kórházi befekvés & 0,2 & 0 & 0 & 0 & 0,2 & 0 & 0 & 0,922 \\
\hline
\end{tabular}

6. táblázat |Agresszív cselekmény következtében kialakult negatív emocionális hatás $(\mathrm{N}=1148)$

\begin{tabular}{|c|c|c|c|c|c|}
\hline & & & és gyak & $(\%)$ & \\
\hline & Soha & Ritkán & Néha & Gyakran & $\begin{array}{l}\text { Majdnem } \\
\text { mindig }\end{array}$ \\
\hline 1. alskála: Kapcsolatromlás a beteg és az ellátó között & & & & & \\
\hline Az adott beteggel kerülöm a kapcsolatot. & 42,6 & 20,7 & 13,5 & 12,9 & 10,3 \\
\hline Nem érzem magam biztonságban, miközben a beteggel dolgozom. & 49,7 & 21,6 & 12,2 & 10,4 & 6,2 \\
\hline Nem érzem magam biztonságban a munkahelyemen. & 59,2 & 21,3 & 10,9 & 5,6 & 3 \\
\hline A beteggel való kapcsolatom zavarttá válik. & 52,8 & 23,3 & 11,7 & 7,7 & 4,6 \\
\hline 2. alskála: Súlyos negatív emocionális hatás az ellátóra & & & & & \\
\hline Lelkiismeret-furdalásom van a beteggel szemben. & 62,5 & 21,4 & 10,5 & 3,9 & 1,7 \\
\hline Sajnálatot érzek a beteg iránt. & 38,3 & 19,3 & 16,2 & 17,4 & 8,7 \\
\hline Szégyellem magam a munkám miatt. & 79,2 & 9,9 & 6,7 & 2,8 & 1,4 \\
\hline Úgy érzem, sikertelen vagyok. & 62,1 & 20 & 11,3 & 4,8 & 1,7 \\
\hline 3. alskála: Ellenséges érzelmek a külvilággal szemben & & & & & \\
\hline Haragot érzek a munkahelyemmel szemben. & 61,8 & 17,7 & 10,9 & 7,1 & 2,5 \\
\hline Úgy érzem, társadalmi problémákkal kell foglalkoznom. & 44,9 & 17,7 & 12,5 & 16,8 & 8,1 \\
\hline
\end{tabular}

7,89 (medián: 7; SD: 4,142; minimum: 4; maximum: 20), a másodikon 7,01 (medián: 6; SD: 3,039; minimum: 4; maximum: 20), a harmadikon 3,96 (medián: 3 ; SD: 2,146; minimum: 2; maximum: 10) pontot értek el a megkérdezettek.

Mann-Whitney-tesztet alkalmaztunk a nem, a diploma megléte és a túlórázás tényének vizsgálata során. A nemek esetében mindhárom alskálánál jelentős különbséget találtunk. A kapcsolatromlás a beteg és az ellátó között alskálán a rangpontszámátlag nők esetében 567,07 , a férfiak esetében 665,15 ( $\mathrm{p}=0,007$ ), a súlyos negatív emocionális hatás az ellátóra elnevezésü alskálán a nők rangpontszámátlaga 567,91, a férfiaké $654,84(\mathrm{p}=$ 0,017), az ellenséges érzelmek a külvilággal szemben alskálán a nők rangpontszámátlaga 561,8, a férfiaké $729,43(\mathrm{p}<0,001)$.

A diplomával rendelkező, illetve nem rendelkező válaszadók között egyik alskálán sem találtunk szignifikáns különbséget $(\mathrm{p}=0,563 ; 0,832 ; 0,378)$. Azon válaszadók, akik havonta egyetlen túlórával sem rendelkeznek, mindhárom alskálán jelentősen kevesebb pontot értek el, mint azok, akiknek van valamennyi túlórájuk. A kapcsolatromlás a beteg és az ellátó között alskálán a rangpontszámátlag a nem túlórázók esetében 488,13 , a túlórázók 
esetében 600,03 ( $\mathrm{p}<0,001$ ), a súlyos negatív emocionális hatás az ellátóra elnevezésű alskálán a nem túlórázók rangpontszámátlaga 486,69, a túlórázóké 600,5 ( $\mathrm{p}<0,001)$, az ellenséges érzelmek a külvilággal szemben alskálán a nem túlórázók rangpontszámátlaga 488,08, a túlórázóké 600,05 (p<0,001).

Kruskal-Wallis-próbával elemeztük az egyes életkori csoportokat, az egészségügyi ellátás szintjét és a munkarendet. Az egyes életkori csoportok között szignifikáns különbség van az agresszív cselekmény következtében kialakult negatív emocionális hatás első és második alskáláján. Megállapítható, hogy minél fiatalabb a válaszadó, annál inkább jelentkezik a beteggel való kapcsolat romlása (rangpontszámátlag: 19-29 év: 685,52, 30-39 év: 639,79, 40-49 év: 564,71, 50 év feletti: 498,8, p<0,001, $\chi^{2}: 41,132$ ) és a súlyos negatív emocionális hatás (rangpontszámátlag: 19-29 év: 644,99, 30-39 év: 619,21, 40-49 év: 562,67, 50 év feletti: 532,34, p = 0,001, $\chi^{2}$ : $15,996)$. A harmadik alskálán nem találtunk jelentős különbséget az egyes életkori csoportok között (rangpontszámátlag: 19-29 év: 600,85, 30-39 év: 607,16, 40-49 év: 568,21, 50 év feletti: 549,54, $\left.\mathrm{p}=0,142, \chi^{2}: 5,445\right)$.

Az egészségügyi ellátás szintjei között szintén csak az első két alskála esetében találtunk szignifikáns különbsé-

7. táblázat |Az IMPACS alskálái a munkarend függvényében $(\mathrm{N}=1148)$

\begin{tabular}{|c|c|c|}
\hline IMPACS-alskálák & Munkarend & $\begin{array}{l}\text { Rangpont- } \\
\text { számátlag }\end{array}$ \\
\hline \multirow{3}{*}{$\begin{array}{l}\text { 1. alskála } \\
\text { Kapcsolatromlás } \\
\text { a beteg és az } \\
\text { ellátó között }\end{array}$} & Állandó délelött & 498,58 \\
\hline & Állandó nappal & 577,38 \\
\hline & $\begin{array}{l}\text { Délelőttös és délutános múszak } \\
\text { váltakozik }\end{array}$ & 507,28 \\
\hline \multirow{4}{*}{$\begin{array}{l}\mathrm{p}<0,001 \\
\chi^{2}=61,994\end{array}$} & Folyamatos (8 órás) & 555,28 \\
\hline & Folyamatos (12 órás) & 665,16 \\
\hline & Állandó éjszaka & 605,65 \\
\hline & Egyéb & 518,57 \\
\hline \multirow{7}{*}{$\begin{array}{l}\text { 2. alskála } \\
\text { Negatív } \\
\text { emocionális hatás }\end{array}$} & Állandó délelőtt & 509,93 \\
\hline & Állandó nappal & 579,56 \\
\hline & $\begin{array}{l}\text { Délelőttös és délutános múszak } \\
\text { váltakozik }\end{array}$ & 533,28 \\
\hline & Folyamatos ( 8 órás) & 549,19 \\
\hline & Folyamatos (12 órás) & 642,30 \\
\hline & Állandó éjszaka & 750,88 \\
\hline & Egyéb & 578,17 \\
\hline \multirow{3}{*}{$\begin{array}{l}\text { 3. alskála } \\
\text { Ellenségesség a } \\
\text { külvilággal }\end{array}$} & Állandó délelőtt & 517,23 \\
\hline & Állandó nappal & 556,73 \\
\hline & $\begin{array}{l}\text { Délelốttös és délutános múszak } \\
\text { váltakozik }\end{array}$ & 528,76 \\
\hline \multirow[t]{4}{*}{$\chi^{2}=36,721$} & Folyamatos (8 órás) & 550,89 \\
\hline & Folyamatos (12 órás) & 640,20 \\
\hline & Állandó éjszaka & 700,46 \\
\hline & Egyéb & 594,52 \\
\hline
\end{tabular}

get. A fekvőbeteg-ellátásban dolgozókra jellemző leginkább a beteggel való kapcsolat romlása (rangpontszámátlag: alapellátás: 531,92, járóbeteg-ellátás: 522,07, fekvőbeteg-ellátás: $592,71, \mathrm{p}=0,003, \chi^{2}$ : 11,326) és a súlyos negatív hatás (rangpontszámátlag: alapellátás: 552,1, járóbeteg-ellátás: 512,8, fekvőbeteg-ellátás: $\left.590,8, p=0,004, \chi^{2}: 10,997\right)$ az agresszív incidens következtében. A harmadik alskálán nem találtunk jelentős különbséget (rangpontszámátlag: alapellátás: 576,73, járóbeteg-ellátás: 527,27, fekvőbeteg-ellátás: 580,02, $\left.\mathrm{p}=0,077, \chi^{2}: 5,122\right)$.

A munkarend alapján felállított csoportok között mindhárom alskálán szignifikáns különbséget találtunk. A 12 órás folyamatos, valamint állandó éjszakás munkarendben dolgozókra van leginkább negatív hatással az agresszív cselekmény átélése, mivel ők érték el a legmagasabb rangpontszámátlagokat (7. táblázat).

Végül felmértük azt is, hogy az elszenvedett agresszió után kitől kapott segítséget a válaszadó. Erre a kérdésre 852 fó válaszolt. Leggyakrabban $(67,1 \%)$ a közvetlen kolléga az, aki segítséget nyújt, ha egy egészségügyi szakdolgozót bántalmazás ér munkahelyén, ezt követi a családtag $(35,2 \%)$ és a közvetlen felettes $(30,2 \%)$. Egyéb válaszlehetőségként hét fó jelezte, hogy megoldotta maga a problémát, két-két fő nyúlt alkoholhoz, fordult bírósághoz vagy biztonsági őrhöz segítségért, egy fö nem érezte szükségét segítség igénybevételének, és egyegy fő volt az, aki önfejlesztő könyveket olvasott, rendőrséghez fordult, saját maga fizetett pszichológushoz ment, és egy fö jelezte, hogy „mellettünk senki nem áll ki” (2. ábra).

\section{Megbeszélés}

Országos, nem reprezentatív kutatásunkban az egészségügyi szakdolgozókat ért agresszív cselekmények gyakoriságát és az átélt agresszív incidensek következményeit vizsgáltuk, összefüggésben különböző szociodemográfiai és munkahelyi tényezőkkel. Felmértük továbbá azt is, hogy a beteg, illetve a hozzátartozó által okozott agresszió után kitől kapnak segítséget a szakdolgozók.

Figyelemre méltó eredmény, hogy az 1201 válaszadó közül csupán 4,4\% volt az, aki egészségügyi pályafutása során még soha nem részesült agresszióban a betegtől vagy hozzátartozójától. Különösen a férfiak szenvedik el a verbális agresszió minden típusát, illetve élik át a tárgyra irányuló agressziót, a ruha megragadását, és szenvednek el enyhe sérülést. Ennek lehetnek okai, hogy:

- a felmérésünkben szereplő férfiak 24\%-a mentésügyben, 14,4\%-a pszichiátrián dolgozik, ahol köztudott az agressziónak való kitettség;

- a társadalom - a nemi szerepekkel kapcsolatos - elvárásából adódik, hogy az agresszió magas kockázatú szituációinál a férfiak fellépését várja el.

Az egészségügyben dolgozó férfiak agressziónak való kitettségéről más kutatók is beszámoltak már [19, 20], 


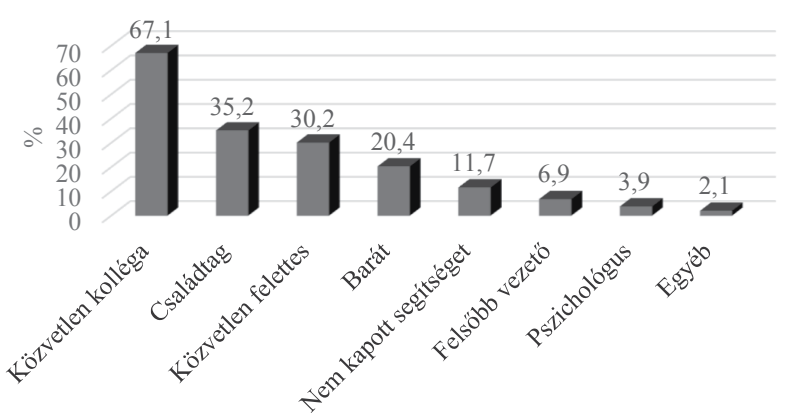

2. ábra

| Agresszió után segítséget nyújtó személyek $(\mathrm{N}=852)$

bár ezen felméréseknél nem különül el az, hogy a férfiak milyen munkaterületen dolgoznak. Az egyes életkori csoportokat vizsgálva megállapítottuk, hogy az 50 év feletti válaszadók éltek át szignifikánsan kevesebb alkalommal csúnya szavakkal történő bántalmazást, fenyegetést és részesültek kiabálásban. Enyhe sérülést leginkább a negyven év alatti korosztály szenvedett el munkája során. Szintén a fiatalabb egészségügyi dolgozók agressziónak való kitettségéról számolt be több kutatás is [19, 21]. Ennek oka lehet, hogy a társadalomban az agressziós és a frusztrációs szint növekszik, ezen belül a fiatalabb korosztályoké hatványozottabban. A nagyobb agressziós és frusztrációs szinttel rendelkező segítők esetén az agreszszió eszkalálódása nagyobb valószínűséggel fordul elő. A pszichiátrián dolgozók agressziónak való kitettségét egyértelmúen igazoltuk.

Az egészségügyi végzettség szintje, vagyis hogy rendelkezik-e diplomával a válaszadó vagy nem, egyik agressziótípus átélési gyakoriságában sem mutatott szignifikáns különbséget. Külföldi kutatások azt találták, hogy a képzettebb dolgozók ritkábban élnek át munkahelyükön agressziót [19, 21]. A fekvőbeteg-ellátásban való munkavállalás, illetve a túlórázás ténye egyértelmúen kockázatot jelent a verbális agresszió összes típusának, valamint a tárgyra irányuló agresszió, a ruha megragadása, az enyhe és a közepes sérülés megtapasztalására. A túlórázás megnövekedett munkahelyi igénybevételhez vezet, ami szintén kockázatot jelent az agresszió átélésére $[6,22,23]$. Eredményeink alapján az állandó éjszakázás több agressziótípus átélésére is fokozott kockázatot jelent. Ilyenek az emelkedett hangnem, a csúnya szavakkal való illetés, a fenyegetés és a kiabálás, a tárgyra irányuló agresszió, a ruha megragadása és az enyhe sérülés elszenvedése. Az emelkedett hangnem és a közepes sérülés megtapasztalása gyakori továbbá a 12 órás folyamatos munkarendben dolgozóknál. Az éjszakai múszak más kutatásban is az agresszió kockázati tényezőjének bizonyult [20]. A túlórázás, a 12 órás folyamatos munkarend, valamint az éjszakai mûszak miatt a szakdolgozók átlagosnál fáradtabbak, emiatt türelmetlenebbek, a toleranciájuk csökkent, aminek következtében kevésbé képesek az agresszió deeszkalációját elérni.
Az agresszív incidens következtében kialakult negatív hatás egyértelmúen a férfiaknál, a havonta valamennyi túlórát végzőknél, a 12 órás folyamatos munkarendben és az állandóan éjszaka dolgozóknál jelentkezik jelentősebb mértékben. Ezek a hatások a következők: megromlik a dolgozó kapcsolata az agresszív beteggel, súlyos negatív emocionális hatás alakul ki, és a külvilággal szemben is ellenséges érzelmek jelentkeznek. A diploma meglétének ténye nem függ össze jelen kutatásban az agreszszív incidens következtében kialakult hatással. Megállapítottuk azt is, hogy minél fiatalabb a válaszadó, annál nagyobb mértékben jelentkezik nála az agresszív cselekmény átélése után az agresszív beteggel való kapcsolat romlása és a súlyos negatív emocionális hatás. Ugyanez a két reakció figyelhető meg a fekvőbeteg-ellátásban dolgozóknál is. A 12 órás folyamatos munkarendben és az állandó éjszaka dolgozók esetében pedig az előbb említett két következményen túl szignifikánsan gyakrabban megjelennek a külvilággal szembeni ellenséges érzelmek is, míg a más munkarendben dolgozóknál ezek kevésbé fordulnak elő. Egy hazai kutatás szerint is a fiatalabb dolgozók az incidens után gyakran zavart ápoló-beteg kapcsolatról számolnak be, kerülik a kapcsolatot a bántalmazó beteggel, és ritkábban éreznek sajnálatot, mint idősebb kollégáik [12].

Megállapítottuk azt is, hogy ha egy egészségügyi szakdolgozót akár verbálisan, akár fizikálisan bántalmaz egy beteg vagy annak hozzátartozója, leggyakrabban a közvetlen kollégáitól, családtagjaitól vagy a közvetlen munkahelyi felettesétől kap segítséget a probléma feldolgozásához. A közvetlen munkatársak támogatását találták az egyetlen előző hazai felmérésben is [12], viszont külföldi felmérések arról számolnak be, hogy az agresszív cselekmény elszenvedése után megromlik az áldozat kapcsolata a munkatársaival $[2,9]$.

A gyakori előfordulás és a súlyos következmények miatt fontos lenne az egészségügyben az agresszió megelőzése. Erre számos lehetőség kínálkozik, például a kommunikációs jártasság fejlesztése [24], olyan tréningek szervezése a dolgozók számára, ahol megtanulják, hogy melyek azok a jelek, amelyek az agresszív viselkedés bekövetkeztére utalnak, így megelőzhető lenne a sérelem [25]. Hazai viszonylatban egészségügyi szakdolgozók részére az ország több pontján szerveztek már egynapos továbbképzést, amely segítséget adhat az agresszív incidensek megelőzésében, számának csökkentésében [26].

A kutatás korlátai között meg kell említeni a reprezentativitás hiányát. Folytatásként szükséges lenne feltárni az oksági viszonyokat, illetve, hogy milyen körülmények vezetnek az agresszióhoz az egészségügyi munkavállalók esetében. Ilyen irány lehetne a munkahelyi igénybevétel szintjének, a kiégettség mértékének az összevetése az elszenvedett agresszióval, amelyről külföldi kutatások már beszámoltak $[6,22,23]$. 
Anyagi támogatás: A szerzők anyagi támogatásban nem részesültek.

Szerzői munkamegosztás: I. T.: Problémafelvetés, magyar nyelvű forrásmúvek felkutatása, hipotézisek megfogalmazása, kutatás lebonyolítása, publikáció megírása. N. A.: Idegen nyelvű forrásmúvek felkutatása, statisztikai adatelemzés, társ témavezető. L. K.: Témavezető, a publikáció végső ellenőrzése. A cikk végleges változatát mindhárom szerző elolvasta és jóváhagyta.

Érdekeltségek: A szerzőknek nincsenek érdekeltségeik.

\section{Irodalom}

[1] Ranschburg, J.: Fear, anger, aggression. [Félelem, harag, agresszió.] Nemzeti Tankönyvkiadó, Budapest, 1995, [Hungarian]

[2] Magnativa, N., Heponiemi, T.: Workplace violence against nursing students and nurses: An Italian experience. J. Nurs. Scholarsh., 2011, 43(2), 203-210.

[3] Farrell, G. A., Shafiei, T.: Workplace aggression, including bullying in nursing and midwifery: A descriptive survey (the SWAB study). Int. J. Nurs. Stud., 2012, 49(11), 1423-1431.

[4] Friedman, R. A.: Violence and mental illness - how strong is the link? N. Engl. J. Med., 2006, 355(20), 2064-2066.

[5] Crilly, J., Chaboyer,W., Creedy, D.: Violence towards emergency department nurses by patients. Accid. Emerg. Nurs., 2004, $12(2), 67-73$

[6] Angland, S., Dowling, M., Casey, D.: Nurses' perceptions of the factors which cause violence and aggression in the emergency department: A qualitative study. Int. Emerg. Nurs., 2014, 22(3), 134-139.

[7] Zampieron, A., Galeazzo, M., Turra, S., et al.: Perceived aggression towards nurses: study in two Italian health institutions. J. Clin. Nurs., 2010, 19(15-16), 2329-2341.

[8] Franz, S., Zeh, A., Schablon, A., et al.: Aggression and violence against health care workers in Germany - a cross sectional retrospective survey. BMC Health Serv. Res., 2010, 10, 51, Available from: http://bmchealthservres.biomedcentral.com/articles/ 10.1186/1472-6963-10-51

[9] Pál, A.: Work-related stress and its correlations with intimidation and violence. [A munkával összefüggő stressz, valamint a munkahelyi megfélemlítés és erőszak összefüggései.] Foglalkozásegészségügy, 2004, 9(5). [Hungarian]

[10] Bimenyimana, E., Poggenpoel, M., Myburgh, C., et al.: The lived experience by psychiatric nurses of aggression and violence from patients in a Gauteng psychiatric institution. Curationis, 2009, 32(3), 4-13.

[11] Gillespie, G. L., Bresler, S., Gates, D. M., et al.: Posttraumatic stress symptomatology among emergency department workers following workplace aggression. Workplace Health Saf., 2013, 61(6), 247-254.

[12] Ivánka, T., Irinyi, T., Rudisch, T.: Occurrences involving aggression among healthcare workers. [Agresszív cselekmények elő- fordulásának vizsgálata egészségügyi szakdolgozók körében.] Nővér, 2014, 27(2), 19-25. [Hungarian]

[13] Act CLIV of 1997 on health. [1997. évi CLIV. törvény az egészségügyról.] Available from: http://net.jogtar.hu/jr/gen/ hjegy_doc.cgi?docid=99700154.TV [Hungarian]

[14] Act C of 2012 on the Criminal Code. [2012. évi C. törvény a Büntető Törvénykönyvről.] Available from: http://net.jogtar. $\mathrm{hu} / \mathrm{jr} / \mathrm{gen} / \mathrm{hjegy}$ doc.cgi?docid=Al200100.TV [Hungarian]

[15] Criminal Statistical System. [Bünügyi Statisztikai Rendszer.] 2015. Available from: https://bsr.bm.hu/SitePages/Excel Megtekinto.aspx? ExcelName=https\%3a\%2f\%2fbsr.bm.hu\%2fSert ettiAdatok\%2fS\%C3\%A9rtettek+sz\%C3\%Alma+az+elk\%C3\%B6v et $\% \mathrm{C} 3 \% \mathrm{~A} 9 \mathrm{~s}+$ helye+szerint.xlsx [Hungarian]

[16] Yudofsky, S. C., Silver, J. M., Jackson, W., et al.: The Overt Aggression Scale for the objective rating of verbal and physical aggression. Am. J. Psychiatry, 1986, 143(1), 35-39.

[17] Needbam, I., Abderbalden, C., Halfens, R. J., et al.: The Impact of Patient Aggression on Carers Scale: instrument derivation and psychometric testing. Scand. J. Caring Sci., 2005, 19(3), 296300.

[18] 63/2011. (XI. 29.) Ministry of Human Resources Decree on the regulation of the rules of professional training of health care providers. [63/2011. (XI. 29.) NEFMI rendelet az egészségügyi szakdolgozók továbbképzésének szabályairól.] Available from: http://net.jogtar.hu/jr/gen/hjegy_doc.cgi?docid=Al 100063 . NEM [Hungarian]

[19] Camerino, D., Estryn-Behar, M., Conway, M. P., et al.: Work-related factors and violence among nursing staff in the European NEXT study: A longitudinal cohort study. Int. J. Nurs. Stud., 2008, 45(1), 35-50.

[20] Magnativa, N., Heponiemi, T.: Violence towards health care workers in a Public Health Care Facility in Italy: a repeated crosssectional study. BMC Health Serv. Res., 2012, 12(1), 108.

[21] Jonker, E. J., Goossens, P. J., Steenbuis, I. H., et al.: Patient aggression in clinical psychiatry: perceptions of mental health nurses. J. Psychiatr. Ment. Health Nurs., 2008, 15(6), 492-499.

[22] Roche, M., Diers, D., Duffield, C., et al.: Violence toward nurses, the work environment, and patient outcomes. J. Nurs. Scholarsh., 2010, 42(1), 13-22.

[23] Magnativa, N.: Workplace violence and occupational stress in healthcare workers: A chicken-and-egg situation-results of a 6-year follow-up study. J. Nurs. Scholarsh., 2014, 46(5), 366376.

[24] Swain, N., Gale, C.: A communication skills intervention for community healthcare workers reduces perceived patient aggression: A pretest-posttest study. Int. J. Nurs. Stud., 2014, 51(9), 1241-1245.

[25] Deák, G.: Hospital security-preventing and managing workplace violence in health care sector. AARMS, 2011, 10(1), 161-171.

[26] Ivánka, T., Irinyi, T., Rudisch, T., et al.: Aggression management programme for healthcare workers. [Agresszió megelőzését célzó továbbképzés egészségügyi szakdolgozók körében.] Nővér, 2014, 27(4), 11-17. [Hungarian]

(Irinyi Tamás,

Szeged, Kálvária sgt. 57., 6725 e-mail: irinyikutatas@gmail.com)

"Timeo Danaos et dona ferentes"

(Félek a görögöktől, még ha ajándékot hoznak is.)

Vergilius 